\title{
Variation Determinants in Building Construction: Ghanaian Professionals Perspective
}

\author{
Richard Oduro Asamaoh ${ }^{1}$ and Kofi Offei-Nyako ${ }^{2}$ \\ Received May 6, 2013 / Revised June 19, 2013 / Accepted November 11, 2013
}

\begin{abstract}
Variation in construction means modification of design, changes in quality, quantity of work including the alteration of standard of materials or goods to be used in the work and the removal from site any kind of material not in accordance in the contract. In Ghana, Variation order has become major issue in the construction industry. This had resulted in cost overruns, delay and in some contracts dispute, between parties. The aim of this paper was to identify the root causes of variation; effects of variations on projects in Ghana and the means of reducing the impact of variation order. The method of the study involved literature review, primary data collection, interview and closed - ended-questionnaires. Mean Scores Method was used to rank the identified factors causing variation. Analysis Of Variance Test was use to test for the significant difference between means among the professional groups. The study revealed that most causes of variation were change of design by client and inadequate working details. Establishment of oversight project management committee and flow of information were identified as means of controlling variations during project administration.
\end{abstract}

Keywords: Variation, Major determinants, Effects, Minimizing Variations

\section{INTRODUCTION}

In construction, variation often occurs when changes are made to the original design after a contract has been signed. It could be additional work or omission needed for hidden problems that were not apparent at the time of the contract. Most standard form of contract includes a clause under which the employer or his representative is able to issue an instruction to the contractor to vary the works which are described in the contract. Project documents include drawings, bills of quantities, specifications, articles of agreement and conditions of contracts. Changes to any of the consistency of a contract document are effected by means of a variation order, initiated by a consultant on behalf of the client usually raised by contractors. Variations are inevitable in construction and are to be expected both at the design and construction stages (Akinsola et al., 1997). The needs of the client may change in the course of the design or construction stage and market conditions may impose changes to the parameters of the contract, and technological developments may alter the design and choice of the method of construction (Arain, et al., 2004).The review of design may bring about changes to optimize design, hence the operations of the project. Furthermore, errors or omissions in construction may also force a change. All these factors and many others necessitate changes that are costly and generally unwelcomed by all parties in the construction industry. Disputes, time overrun, cost overrun and misunderstandings are the outcome when variations arise, often causing disruptions to the smooth running of projects (Ibbs, et al, 2001). The main objective of this study is to identify the major factors causing variation in building construction projects in Ghana, using an opinion survey and suggest possible ways of minimizing the impact of variations orders in building construction

\section{LITERATURE REVIEW}

Client, consultant, contractor and external factors are the main causes of variations (Arain, et al., 2004). There are many reasons that may cause the stakeholders to initiate variations during project administration. Mohammad et al (2010), identified financial challenges, aesthetics, changes in drawings, weather, geological and geotechnical as some of the reasons leading to variations. The client, as the project initiator, plays a major role in building construction project from the inception to the completion states, hence, influences the occurrence of variations.

The client spells out the needs and objectives of the projects, establishes the scope of works and the required quality standards (Arain, et al., 2004). During the construction stage, client initiates variation orders due to cost, aesthetic and other reasons through the consultant (Mohammad et al 2010). The client relies on the expertise of the consultant, whose responsibility is to carry out the design and supervise the works on site. The recent developments in construction management such as new technologies and financial accountability require all professionals related to project management in the construction industry to be involved in the early stages of project, in order to minimize the causes and impact of

\footnotetext{
${ }^{1}$ Research Scientist, CSIR-Building and Road Research Institute, Kumasi, Ghana, asamoaho@yahoo.com (*Corresponding Author)

2 Research Scientist, CSIR-Building and Road Research Institute, Kumasi, Ghana, kofioffeinyako@yahoo.com
} 
variation orders (Gyadu-Asiedu, 2009).

Members of the consultant team also have the control to effect variation orders on behalf of their clients (Mohammad et al 2010). Sometimes, it becomes difficult for contractors to interpret ambiguous designs and inadequate working drawings. It is important for the contractors to notify the consultant to avoid delays in issuing variation order, which may result in losses in terms of idle labour and plant time (Fugar et al, 2010). It is the contractor's responsibility to advise the consultant to issue a variation order when a technical problem is discovered. Variation orders initiated due to the default of a contractor are frown upon by the client. Situations that give rise to default include defective workmanship, unfamiliarity with local conditions, poor management and lack of efficient communication (Randa, et al, 2009). When contractors or their subcontractors discover an obvious discrepancy in the contract document, a request is submitted to the consultant for review and variation order is issued afterwards (Levy, 2002).

Design variations and variations by the client are identified as key risks in construction projects in China (Zou et al.2007). Sun and Meng (2004) grouped factors causing variation into five groups, namely project related, client related, design related, contractor related and external factors. Arain and Pheng (2006) identified four origin causes of variation orders. These were clients, consultants, contractors and other changes. Ruben (2008) also indentified the factors influencing the occurrences of variation orders in three main factors which include nature of the project, complexity of the project and procurement methods which include the traditional and the non traditional methods.

Variation at every stage of construction process has an effect on project administration. Several published papers by different researchers have identified various effects of variation order. Ma et al (2010) identified time overrun and cost overall as the main effect of variation order. Keane et al (2010) also identified cost overrun, time overrun and dispute among parties in contract. Arain and Low (2005) sum up the effects of variation to include the following: increase in project cost, hiring new professionals, increase in overhead expenses, and delay in payment, quality degradation, productivity degradation, procurement delay, rework and demolition, logistics delays, tarnished firm's reputation, poor safety conditions, poor professional relations, additional payments for contractor, disputes among professionals and completion schedule delay. In order to manage variation orders, proper guidelines must be followed. Knowing and carefully reviewing contracts, following the proper variation procedures and constantly taking into consideration the risks associated with poor records keeping will help minimize the effect of variation orders in construction.

\section{METHOD OF THE STUDY}

In determining the sample for the study, it was identified that as of 23th January, 2013, a total of one thousand one hundred and eleven $(1,111)$ building professionals had registered with their various professional institutions in Ghana( i.e. Ghana Institution of Engineers, Ghana Institution of Architect and Ghana Institution of Surveyors (ghisonline.org/47/31/registeredmembers (Q.S.), arcghana.org/member list, ghie.org.gh). In order to obtain the sample size for the survey, a statistical method was used in deriving the sample size for all the selected professionals for the study using a formula by Israel (1992). The formula (1) as stated below;

$n_{0}=\frac{Z^{2} p q}{e^{2}}$

Where,

$n_{0}=$ the sample size

$Z^{2}=$ the abscissa of the normal curve that cuts off an area $\alpha$ at the tails ( $1-\alpha$ equals the desired confidence level, e.g., $95 \%$ )

$e=$ the desired level of precision

$p=$ the estimated proportion of an attribute that is present in the population

$q=1-p$

The value for $\mathrm{Z}$ is found in statistical tables which contain the area under the normal curve.

Assume there is a large population but that the variability is not known in the proportion that will adopt the practice; assume $\mathrm{p}=.5$ (maximum variability). Furthermore, suppose we desire a 95\% confidence level and $\pm 5 \%$ precision (Israel, 1992). Table 1 below indicates the Sample size distribution for selected building professionals in Ghana. The purpose of the study was to identify the causes, effects and remedies of variation from the professionals' perspective. The client was not considered in the distribution of questionnaires.

TABLE I

SAMPLE Size Distributions For SOME SELECTEd BUILding PROFFESSIONALS

\begin{tabular}{c|c}
\hline \multicolumn{2}{c}{ PROFFSSIONALS } \\
\hline Professionals & Registered Professionals \\
\hline Quantity Surveyors & 315 \\
\hline Architects & 438 \\
\hline Civil Engineers & 358 \\
\hline Total & 1,111 \\
\hline (Source: Website of all selected professional as 23 ${ }^{\text {rd }}$ January, 2013)
\end{tabular}

The table 2 below indicates sample size determination by Israel (1992). According to the table a population of more than thousand $(1,000)$ will require sample size of 333. Assuming a return rate of $45 \%$ the sample size for the questionnaire distribution was increased to 350 . 
TABLE II

SAMPLE DISTRIBUTION

\begin{tabular}{|c|c|c|c|c|}
\hline \multirow{2}{*}{ Size of Population } & \multicolumn{4}{|c|}{ Sample Size (n) for Precision (e) of: } \\
\hline & $3 \%$ & $5 \%$ & $7 \%$ & $10 \%$ \\
\hline 500 & $\mathrm{a}$ & 222 & 145 & 83 \\
\hline 600 & $\mathrm{a}$ & 240 & 152 & 86 \\
\hline 700 & $\mathrm{a}$ & 255 & 158 & 88 \\
\hline 800 & $\mathrm{a}$ & 267 & 163 & 89 \\
\hline 900 & $\mathrm{a}$ & 277 & 166 & 90 \\
\hline 1,000 & $\mathrm{a}$ & 286 & 169 & 91 \\
\hline 2,000 & 714 & 333 & 185 & 95 \\
\hline 3,000 & 811 & 353 & 191 & 97 \\
\hline 4,000 & 870 & 364 & 194 & 98 \\
\hline 5,000 & 909 & 370 & 196 & 98 \\
\hline 6,000 & 938 & 375 & 197 & 98 \\
\hline 7,000 & 959 & 378 & 198 & 99 \\
\hline 8,000 & 976 & 381 & 199 & 99 \\
\hline 9,000 & 989 & 383 & 200 & 99 \\
\hline 10,000 & 1,000 & 385 & 200 & 99 \\
\hline 15,000 & 1,034 & 390 & 201 & 99 \\
\hline 20,000 & 1,053 & 392 & 204 & 100 \\
\hline 25,000 & 1,064 & 394 & 204 & 100 \\
\hline 50,000 & 1,087 & 397 & 204 & 100 \\
\hline 100,000 & 1,099 & 398 & 204 & 100 \\
\hline$>100,000$ & 1,111 & 400 & 204 & \\
\hline $\begin{array}{l}\mathrm{a}=\text { Assumption of norr } \\
\text { entire population shoul }\end{array}$ & $\begin{array}{l}\text { ulation } \\
\text { npled. }\end{array}$ & oor & Iane, & ). $\mathrm{Tl}$ \\
\hline
\end{tabular}

The data was analyzed using the Mean Score Method with weighting scale of 1 to 4 based on simplicity and suitability for evaluating the significance of each factor, using the respondent's own judgment and working experience in the construction industry. A four - point scale was used to calculate the mean score for each factor. The result was then used to determine the relative ranking of each factor by assigning ranking to the mean score (with low mean score assigned low ranks and high scores allocated high ranks). The Mean Score (MS) for each factor was computed by using the formula (2) as stated:

$M S=\frac{\sum(F \times S)}{N}$

Where $\mathrm{S}$ is the score given to each factor by respondents and ranges from 1 to 4 in which "1" - is not significant", "2" - Less significant", "3 “- significant" and "4" extremely significant; is frequency of responses to each rating $(1-4)$, for each factor; and $\mathrm{N}$ is the total number of responses concerning that factor. Further analysis was done using a statistical tool (Analysis of Variance Test - ANOVA Test) to test for the significant difference means between the professionals on the factors causing variation in the Ghanaian building industry.

\section{RESULTS AND DISCUSSION}

Three hundred and fifty (350) questionnaires were distributed among the professionals and 250 of them were returned but only 93 were responsive.

TABLE III

RESPONSIVENESS OF QUESTIONNAIRES

\begin{tabular}{c|c|c|c}
\hline Professionals & $\begin{array}{c}\text { Questionnaires } \\
\text { Returned }\end{array}$ & $\begin{array}{c}\text { Responsive } \\
\text { Questionnaires }\end{array}$ & $\begin{array}{c}\text { Percentage of } \\
\text { responsiveness }\end{array}$ \\
\hline $\begin{array}{c}\text { Quantity } \\
\text { Surveyors }\end{array}$ & 77 & 29 & 37.7 \\
\hline Architects & 90 & 32 & 35.6 \\
\hline $\begin{array}{c}\text { Civil } \\
\text { Engineers }\end{array}$ & 83 & 32 & 38.5 \\
\hline Total & 250 & 93 & 37.2 \\
\hline
\end{tabular}

\section{A. Respondents' Profile}

Respondents' experiences were taken into account in analyzing the data as this information indicates the reliability of the data. The profile of the respondents' working experience in the construction industry is illustrated in Table 3. From the data collected it was found that $50 \%$ of the respondent have worked up to 10 years, $36 \%$ have worked for $10-20$ years and $14 \%$ of the professionals have worked above 20 years.

TABLE IV

EXPERIENCE OF PROFESSIONALS

\begin{tabular}{c|c|c}
\hline $\begin{array}{c}\text { Years of Working } \\
\text { Experience }\end{array}$ & $\begin{array}{c}\text { Number of } \\
\text { Professionals }\end{array}$ & $\begin{array}{c}\text { Percentage of } \\
\text { selected Professionals }\end{array}$ \\
\hline Up to 10 & 46 & 50 \\
\hline $10-20$ & 34 & 36 \\
\hline 20 years and above & 13 & 14 \\
\hline Total & 93 & 100 \\
\hline
\end{tabular}

\section{B. Causes of Variation Order}

For the purposes of this study, all the factors already identified by the previous authors including Arain (2005), Keane (2010) and Fugar (2010) were summarized into 25 factors to identify the most prevailing factor in the building industry of Ghana. The table 5 below indicates the factors and their respective mean score rankings. 
TABLE V

THE MEAN SCORES AND RANKING OF ALL 25 SELECTED FACTORS CAUSING VARIATION IN THE GHANAIAN CONSTRUCTION INDUSTRY

\begin{tabular}{|c|c|c|c|c|c|c|c|}
\hline \multirow{3}{*}{ No } & \multirow{3}{*}{ Causes of Variation Order } & \multicolumn{6}{|c|}{ No of Respondents Scoring $(\mathrm{N}=93)$} \\
\hline & & \multicolumn{4}{|c|}{$M S=\frac{\sum(F \times S)}{N}$} & \multirow[t]{2}{*}{ Mean } & \multirow[t]{2}{*}{ Rank } \\
\hline & & 4 & 3 & 2 & 1 & & \\
\hline 1 & Change of design/scope by client & 76 & 17 & 0 & 0 & 3.82 & 1 \\
\hline 2 & Inadequate working drawing Details & 63 & 17 & 13 & 0 & 3.54 & 2 \\
\hline 3 & Clients financial difficulties & 51 & 21 & 17 & 4 & 3.28 & 3 \\
\hline 4 & Difficult site conditions & 55 & 17 & 13 & 8 & 3.28 & 3 \\
\hline 5 & Change in specifications & 42 & 42 & 0 & 9 & 3.26 & 5 \\
\hline 6 & Lack of coordination & 21 & 42 & 30 & 0 & 2.90 & 6 \\
\hline 7 & Design complexity & 25 & 38 & 25 & 5 & 2.89 & 7 \\
\hline 8 & Inadequate project objectives & 38 & 17 & 21 & 17 & 2.82 & 8 \\
\hline 9 & Consultant's lack of judgments and experience & 30 & 25 & 25 & 13 & 2.77 & 9 \\
\hline 10 & Lack of knowledge and availability of materials and equipment & 21 & 38 & 21 & 13 & 2.72 & 10 \\
\hline 11 & Unavailability of labour & 23 & 27 & 34 & 9 & 2.69 & 11 \\
\hline 12 & Change in government regulation & 30 & 17 & 25 & 21 & 2.60 & 12 \\
\hline 13 & Unfamiliarity with local conditions & 14 & 38 & 26 & 15 & 2.55 & 13 \\
\hline 14 & Impediment in prompt decision - making & 15 & 32 & 31 & 15 & 2.51 & 14 \\
\hline 15 & Discrepancies between contract documents & 13 & 25 & 51 & 4 & 2.51 & 14 \\
\hline 16 & Lack of specialized construction manager & 13 & 30 & 37 & 13 & 2.46 & 16 \\
\hline 17 & Unavailability of equipment & 15 & 25 & 38 & 15 & 2.43 & 17 \\
\hline 18 & Weather conditions & 8 & 38 & 30 & 17 & 2.40 & 18 \\
\hline 19 & Non Compliant design with clients & 2 & 40 & 40 & 11 & 2.35 & 19 \\
\hline 20 & Technology change & 13 & 16 & 47 & 17 & 2.27 & 20 \\
\hline 21 & Firm nature of the client & 11 & 19 & 44 & 19 & 2.24 & 21 \\
\hline 22 & Contractor's desired profitability & 17 & 13 & 33 & 30 & 2.18 & 22 \\
\hline 23 & Health and safety considerations & 0 & 25 & 47 & 21 & 2.04 & 23 \\
\hline 24 & Lack of contractor's involvement in design & 0 & 25 & 38 & 30 & 1.95 & 24 \\
\hline 25 & Socio-cultural factor & 0 & 24 & 27 & 42 & 1.81 & 25 \\
\hline
\end{tabular}

The respondents identified the 10 main causes of variation orders as change of design/scope by client as first, inadequate working drawing details as second, client financial difficulty, change in specifications and difficult site conditions were all ranked as third respectively, ranked, lack of coordination was ranked as sixth, design complexity was ranked as seventh, inadequate project objectives as eight and consultant's lack of judgment and experience as ninth and the tenth factor was lack of knowledge and availability of labour These factors were considered to be most influential causes of variation order in Ghana as indicated in table 4.

\section{1) Change of plans or scope by owner:}

Change of plan or scope of project is one of the most significant causes of variation in construction projects and is usually the result of insufficient planning at the project definition stage, or because of lack of involvement of the owner in the design phase (Arain et al., 2004). This cause of variations affects the project severely during the later phases.

\section{2) Inadequate working drawing details:}

To convey a complete concept of the project design, the working drawings must be clear and concise. Insufficient working drawing details can result in misinterpretation of the actual requirement of a project
(Arain et al., 2004). Thorough reviewing of design details would assist in minimizing variations.

\section{3) Client's financial difficulties:}

The owner of the facility may run into difficult financial situations that force him to make changes in an attempt to reduce cost. Owner's financial problems affect project progress and quality (Mohammed, 2010). Proper planning and review of project cash flow would be effective in eliminating this problem.

\section{4) Change in Specification:}

Change in design for improvement by the consultant is a norm in contemporary professional practice (Arain et al., 2004). The changes in design are frequent in projects where construction starts before the design is finalized (Mohammed, 2010). Design changes can affect a project adversely depending on the timing of the occurrence of the changes.

\section{5) Design complexity:}

Complex designs require unique skills and construction methods (Arain et al., 2004). Complexity affects the flow of construction activities, whereas simple and linear construction works are relatively easy to handle. Hence, complexity may cause major variations in construction projects. 


\section{Effect of variation order in building projects}

The selected professional groups were asked to list the effects of variation orders in building projects. Five main effects were listed by the selected building professionals. The 6 table below shows the effects. Eighty percent $(80 \%)$ listed cost overrun and time overrun respectively as the main effects of variation order. Sixty percent $(60 \%)$ listed Disputes between parties to a contract as the next.

TABLE VI

EFFECT OF VARIATION ORDER IN BUILDING WORK

\begin{tabular}{c|c|c}
\hline No. & Effect of Variation Order in Building Works & $\begin{array}{c}\text { Percentage } \\
(\%)\end{array}$ \\
\hline 1 & Cost Overrun & 80 \\
\hline 2 & Time Overrun & 80 \\
\hline 3 & Disputes between parties to the contract & 60 \\
\hline 4 & Optimum Cost Reduction & 30 \\
\hline 5 & Time Reduction & 10 \\
\hline
\end{tabular}

\section{Minimizing variation}

The respondents were asked to indicate how variation orders can be minimized in order to ensure that projects are completed on time and also within the proposed project estimated cost. Respondents indicated that for private projects, a report system should be instituted between the client, consultant and contractors for effective management of project status. And for public funded projects, an oversight committee should be established to monitor projects on the basis of timelines, budgetary allocation, and change of scope or design in order to prevent cost overruns.

Establishment of cost control systems to provide for accurate recording of each project's expenses, from initiation to completion and to produce timely reports, as well as monitoring all project expenditure regardless of the size of the project as the most efficient means of minimizing variation.

Respondents indicated that establishment of a process to identify major construction needs and preparing budgets with appropriate contingencies that meet and incorporate a long-term financial plan and also develop and maintain implementation procedures to meet project objectives.

Respondents also suggested the inclusion of knowledgeable construction management expertise on projects, in order to ensure the quality of the day-to-day management of projects.

\section{STATISTICAL VERIFICATION}

Statistical verification was determined using Analysis Of Variance Test (ANOVA Test) to establish the difference of means between the professional groups on the first 10 factors causing variation in the Ghanaian building industry. The table 7 below shows each factor and its respective mean $\mathrm{P}$ and $\mathrm{F}$ values.

TABLE VII

STATISTICAL VERFICATION TEST FOR FIRST TEN FACTORS

\begin{tabular}{c|c|c|c|c|c|c|c|}
\hline & Quantity Surveyors \\
Professional Groups & $\begin{array}{c}\text { Civil Engineers } \\
(\mathrm{b})^{\mathrm{a}}\end{array}$ & $\begin{array}{c}\text { Architects } \\
(\mathrm{c})^{\mathrm{a}}\end{array}$ & $F$ & $\mathrm{P}$ & $\mathrm{Bonferroni}$ \\
\hline
\end{tabular}

Statement: Causes of variation Order

\begin{tabular}{|c|c|c|c|c|c|c|}
\hline 1. Change of design/scope by client & 3.80 & 3.76 & 3.90 & 1.21 & 0.303 & \\
\hline 2. Inadequate working drawing details & 3.83 & 3.82 & 3.81 & 0.02 & 0.978 & \\
\hline 3. Client financial difficulties & 3.76 & 3.64 & 3.65 & 0.45 & 0.640 & \\
\hline 4. Difficult site conditions & 3.24 & 3.24 & 3.29 & 0.02 & 0.978 & \\
\hline 5. Change in specifications & 3.55 & 3.24 & 3.67 & 2.90 & $0.060 *$ & $\mathrm{~b} * \mathrm{c}$ \\
\hline $\begin{array}{l}\text { 6. Lack of coordination amongst client and } \\
\text { professionals }\end{array}$ & 3.38 & 3.30 & 3.26 & 0.18 & 0.835 & \\
\hline 7. Design Complexity & 3.24 & 3.21 & 2.81 & 2.43 & $0.094 *$ & \\
\hline 8. Inadequate project objectives & 3.00 & 2.73 & 2.94 & 0.51 & 0.600 & \\
\hline $\begin{array}{l}\text { 9. Consultant's lack of judgments and } \\
\text { experience }\end{array}$ & 3.17 & 2.97 & 3.23 & 0.58 & 0.568 & \\
\hline $\begin{array}{l}\text { 10. Lack of Knowledge and availability of } \\
\text { materials and equipment }\end{array}$ & 3.20 & 3.70 & 3.97 & 2.21 & $\begin{array}{c}0.000^{*} \\
*\end{array}$ & $a * b ; a * c$ \\
\hline Total Mean & 3.42 & 3.42 & 3.45 & & & \\
\hline
\end{tabular}

Likert scale scores: $1=$ not significant; $4=$ extremely significant. ${ }^{a}$ All data in these columns are means.

* $\mathrm{P}<0.10$. ** $\mathrm{P}<0.05 . \mathrm{F}=$ ANOVA Test Value.

The result from table 7, apart from change in specification, design complexity and lack of knowledge and availability of materials and equipment, all the other factors shows no difference between the professional groups. There was a significant difference between Civil Engineers and Architects on the factor change in specifications $(\mathrm{F}=2.90, \mathrm{p}<0.06)$. There was a difference between Quantity Surveyors and Civil Engineers and
Quantity Surveyors and Architects on the factor lack of Knowledge of availability of materials and equipment with $\mathrm{F}=2.21$ and $\mathrm{p}<0.001$. Also the table indicates a difference statistically between the professionals on the factor Design Complexity but because the $\mathrm{p}$ value is close to $0.1(\mathrm{~F}=2.43: \mathrm{p}<0.094)$ it does not show the specific difference amongst the professionals.

\section{CONCLUSION}


There are a lot of factors causing variation orders in the building sector of the construction industry in Ghana. The professionals in Ghana identified change of design/ scope by client as the most influential factor causing variation orders. Cost overrun was revealed as the leading effect of variation orders. The study identified establishment of oversight project management committee and flow of information as methods of minimizing variation order.

\section{RECOMMENDATIONS}

In order to control the causes and effects of variations in construction project, the study recommends the following:

Feasibility study and adequate planning is required by all parties before works start on site. Consultants should do a thorough review of design and working drawings and contract documents by consulting team. Works should be supervised with an experienced and dedicated supervisor. There should be an improve communication between all parties at all times. Consultants should ensure that all project specifications are within the approved construction budget. Value engineering system should be part of every construction project.

\section{REFERENCES}

[1] A.O. Akinsola, K.F. Potts, I. Ndekugri, F.C. Harris, "Identification and Evaluation of Factors Influencing Variations on Building Projects", International Journal of Project Management, vol. 15, no. 4, pp. 263-267, 1997.

[2] F.M. Arain, S. Assaf, S.P. Low, "Causes of Discrepancies between Design and Construction", Architectural Science Review, vol. 47, no. 3, pp. 237-249, 2004.

[3] F.M. Arain, S.P. Low, "The Potential Effects of Variation Order on Institutional Buildings Projects", Facilities, vol. 23, no. 11/12, pp. 496-510, 2005.

[4] F.M. Arain, S.P. Low, "Effective Management of Contract Variations using a Knowledge Based Decision Support System", Centre for Education in Built Environment, Working Paper No. 10, 2005.

[5] D. Bower, "A systematic approach to the evaluation of indirect costs of contract variations", Construction Management and Economics, vol. 18, no. 3, pp. 263-268, 2000.

[6] F.D.K. Fugar, A.B. Agyakwah-Baah, "Delays in building construction projects in Ghana", Australasian Journal of Construction Economics and Building, vol. 10, no. 1/2, pp. 103116, 2001.

[7] W. Gyadu-Asiedu, "Assessing Construction Project Performance in Ghana: Modeling Practitioners' and Clients' Perspectives", Dissertation, Eindhoven University of Technology, Netherlands, 2009.

[8] G.D. Israel, "Determining Sample Size", Agricultural Education and Communication Department, UF/IFAS Extension, Fact sheet PEOD6, 1992.

[9] C.W. Ibbs, "Quantitative Impacts of Project Change: Special Issues", Journal of Construction Engineering and Management, vol. 123, no. 3, pp. 308-311, 2001.

[10] P. Keane, B. Sertyesilisik, A. Ross, "Variations and Change Orders on Construction Projects", Journal of Legal Affairs and Dispute Resolution in Engineering and Construction, vol. 2, no. 2, pp. 8996, 2010.

[11] S.M. Levy, "Project Management in Construction", $4^{\text {th }}$ ed., Columbus, 2002.

[12] McGraw-Hill T. Ma, A. Olifent, J. Zuo, "Towards the minimization of variations in design and build projects", Proceedings of the 2010 Australasian Universities Building Education Association, 35th Annual Conference: AUBEA, pp. 1$13,2010$.
[13] N. Mohammad, A.I. Che Ani, R.A.O.K. Rakmat, M.A. Yusof, "Investigation on the Causes of Variation Orders in the Construction of Building Project - A Study in the State of Selangor, Malaysia", Journal of Building Performance, vol. 1, no. 1, pp. 73-82, 2010.

[14] R. Ndihokubwayo, "An analysis of the impact of variation orders on project performance", Dissertation, Cape Peninsula University of Technology, South Africa, 2008.

[15] R.S.M. Jawad, M.R.B. Abdulkader, A.A.A. Ali, "Variation Orders in Construction Projects", Journal of Engineering and Applied Sciences, vol. 4, no. 3, pp. 170-176, 2009.

[16] R.V. Krejcie, D.W. Morgan, "Determining Sample Size for Research Activities", Educational and Psychological Measurement, vol. 30, pp. 607-610, 1970.

[17] M. Sun, X. Meng, "Taxonomy for change causes and effects in construction projects", International Journal of Project Management, vol. 27, no. 6, pp. 560-572, 2009.

[18] J. Watson, "How to Determine a Sample Size: Tip sheet \#60", University Park, PA: Penn State Cooperative Extension, 2001.

[19] P.X.W. Zou, G. Zhang, J. Wang, "Understanding the key risks in construction projects in China", International Journal of Project Management, vol. 25, no. 6, pp. 601-614, 2007.

[20] http://www.arcghana.org/memberlist (assessed 23rd January, 2013)

[21] http//www.ghie.org.gh (assessed 23rd January, 2013)

[22] http//www.ghisonline.org/47/31/Registered-Members (assessed 23rd January, 2013) 